\title{
WHICH GENDER TRAITS PREFER UNIVERSITY STUDENTS TO MANAGE A CRISIS?
}

\author{
Sonia Agut, Francisco Lozano, Rosana Peris \\ Dept. of Psychology. Universitat Jaume I (SPAIN)
}

\begin{abstract}
Few women reach top leadership positions so they are concentrated at low and middle levels of management. This phenomenon was labeled as glass ceiling decades ago. The similarity between stereotypes of men and stereotypes of leaders makes women's advancement into leadership roles difficult (think manager-think male association). Moreover, when women climb to upper management jobs, they still face another form of discrimination, because they are often appointed to positions that are more precarious and associated with a higher risk of failure than those occupied by men. This is called glass cliff (Ryan \& Haslam (2005)). In this case, it is assumed that women due to their communal attributes may appear to be a better fi to deal with the socioemotional challenges that (potential) crises present. In this context, people are more likely to make the alternative think crisisthink female association. The sample was composed of 240 Spanish university students ( $n=96$ men and $n=144$ women). Against our expectations, the results show that the masculine characteristics (e.g., strong personality) are considered more suitable for a top managerial job than the feminine traits (e.g., affectionate). In addition, boys and girls differ in this issue: male students prefer to a greater extent masculine traits in comparison to female students, whereas female students prefer to a greater extent feminine traits in comparison to male students. These findings show that traits associated traditionally to men are seen more appropriate among highly-qualified people to organizational management even in troubling times. The implications of the results for education, university teachinglearning process, future research guidelines, and limitations of the study are also discussed.
\end{abstract}

Keywords: Gender traits, think crisis-think female, university students.

\section{INTRODUCTION}

Women have joined massively both the labour market and the education system, especially during the second half of the twentieth century. However, from a transversal perspective, their situation is not analogous to men position. This is reflected in the difficulty of many women to fully develop a professional career that allows them reach top management positions, since there is the so-called glass ceiling that prevents them from getting there. Gender stereotypes and the perceived incongruity between the leadership role in these contexts and female gender role is one of the main mechanisms that helps to understand the existence of glass ceiling. Moreover, when they finally reach upper management positions, still copes with another form of discrimination, the so-called glass cliff [1]. It alludes to the fact that women are often appointed to positions that are more precarious, and associated with a higher risk of failure than those occupied by men [1, 2, 3,]. In this case, gender stereotypes benefit women. Communal attributes may appear to be a better fi to deal with the socioemotional challenges that (potential) crises present.

\subsection{Few women in top management: the glass ceiling metaphor}

The inequality of women in the labour world is very well reflected in the difficulty of many of them, in comparison to men, to pursue a career that would lead them to positions of responsibility in government or private companies. In fact, women rarely reach the top, and get stuck in jobs that are below their potential.

This invisibility in leadership and decision-making positions has led to different authors $[4,5,6,7]$ as well as government agencies [8], show and denounce the existence of so-called glass ceiling. The first use of this term is documented in 1984, by the editor of a magazine, Gay Bryant. It was popularized in 1986 when the glass ceiling was the central theme of an article in Wall Street Journal [9]. This term is a metaphor that refers to the "invisible" barriers that women face in most organizations when trying to access management positions [10]. These barriers prevent many women with personal and professional capacity to positions in management environments and promoted within them [11]. The most important barriers include the occupational segregation and employment discrimination. 
However, there is an especially relevant factor in understanding why the glass ceiling appears. We refer to the influence of gender stereotypes [12]. In fact, the glass ceiling is actually a result of gender stereotypes and the expectations they generate on how women behave and how should behave in leadership positions [13]. Gender stereotypes are a set of socially shared beliefs about the characteristics and habitual behaviours of men and women [14], applied indiscriminately to all members of the group. Stereotypes encompass a descriptive component (i.e., how the members of the group are and behave) and a prescriptive component (i.e., how women/men should be and behave). From a descriptive point of view, it is often assumed that men are independent, dominant, aggressive, assertive, confident, and intellectual, while women are emotional, compassionate, homey, submissive, and gentle [15]. The second component of gender stereotypes, the prescriptive dimension refers to the beliefs about how men and women should be and behave. For example, the female stereotype includes requirements such as that a woman should have interpersonal skills, be passive, docile, show interest and cooperate with others. On the contrary, men should have initiative, be ambitious or aggressive. The female dimension of gender stereotype is called communal, while the male dimension is named instrumental or agentic [13]. Agentic qualities are precisely those most emphasized and valued in the performance of managerial roles [16].

\subsection{Women as managers in crisis companies: the glass cliff metaphor}

Moreover, the scarce number of women that leaves behind low and middle management jobs and reaches top management positions, still copes with another form of discrimination, the so-called glass cliff [1]. It alludes to the fact that women are often appointed to positions that are more unstable, and associated with greater chance of failure than those occupied by men [1, 2, 3]. In the recent years, empirical evidence demonstrates and replicates it in several contexts as well as in different countries [17]. Individuals prefer to select women to lead under struggling conditions but like better men to lead in more thriving situations $[18,19]$.

The literature analyses the processes underlying glass cliff, and the explanation that has received the most attention from researchers is gender stereotypes [17]. Women are considered better crisis managers, since it is assumed that they have the communal attributes which seems to be particularly useful in times of crisis or risk rather than the agentic ones. The ideal managers of unsuccessful companies are associated with the female stereotype (e.g., understanding, intuitive, tactful) rather than the characteristics that are stereotypically male (e.g., decisive, assertive) [20]. Thus, in these contexts, people are more likely to make the alternative think crisis-think female association [3], rather than the association of manager with masculinity. This suggests that there is no single prototype of a good leader across all situations [21], rather is context-dependent [3]; hence when the context changes, the stereotypical characteristics of women and the requirements of leader roles may be perceived more congruent [22].

This underlies some hostility against women. In fact, sexism is pointed as another of the contributing factors [17, 23, 3], because choosing a woman in precarious circumstances may be motivated by the wish to see her fail. And when failure comes, women must deal with the consequences and are more exposed to blame and humiliation [1].

In this context, this study is conducted with the aim of analysing which gender traits are considered more suitable in a leader in an organization which is facing a crisis and also to explore the gender differences in this topic.

\section{METHODOLOGY}

\subsection{Sample and procedure}

The sample was composed of 240 university students from several degree courses in Spain. There were 144 females $(60 \%)$ and 96 males $(40 \%)$, aged between 20 and 50 years (mean $=23.58, \mathrm{SD}=$ 3.69). These students completed the instruments of the study in groups of three in the laboratory under the guidance of a member of the research team, who explained the content of the scales and cleared up any possible doubts. Confidentiality of their responses was fully guaranteed.

\subsection{Variables and measures}

The variables analysed in the students were the following: 
- Gender. Male - female.

- Age. Years old.

- Gender attributes. The participants were asked to indicate how much several characteristics were suitable to the performance of a top managerial position on a 7-point scale ranging from 1 (totally disagree) to 7 (totally agree). The characteristics were 18 items that make up the short version of the Bem Sex Roles Inventory (BSRI) [24] and that resulted to be stereotypically masculine and stereotypically feminine in the cultural context of the country of where this study was carried out [25]. Nine of the items evaluate stereotypically masculine characteristics (e.g., aggressive, $\alpha=.75$ ) and the other nine items evaluate stereotypically feminine characteristics (e.g., warm, $\alpha=.80$ ).

\subsection{Data analyses}

Data analysis was performed using the SPSS statistics computer program. Descriptive analysis, correlations (Pearson's r), and internal consistencies (Cronbach's a) were performed. In order to achieve the first study objective, one $t$ test was carried out where the mean score of masculine attributes was compared to the mean score of feminine attributes. Secondly, we performed an ANOVA in which the factor was gender and the dependent variables were masculine and feminine attributes. Also we did an ANOVA for each personal attribute.

\section{RESULTS}

The Table 1 shows the means, standard deviations (SD), internal consistencies (Cronbach's $\alpha$ ), and the correlations of the study variables. The mean scores reveal that this sample considered the personal attributes moderate\&ely suitable for performing a managerial job in a crisis company. Masculine and feminine attributes subscales were sufficiently consistent internally, since Cronbach's $\alpha$ met the criterion of 0.70 [26]. As we can see at Table 1, gender correlated negatively with masculine attributes and positively with feminine attributes. As well, age correlated positively with feminine attributes.

In addition, the results of $t$ test confirmed $\{t(239,1)=11.90, p<.001\}$, in global terms, masculine attributes mean score $(M=4.28, S D=0.82)$ was significantly higher than feminine attributes mean score $(\mathrm{M}=3.37, \mathrm{SD}=0.80)$.

Table 1: Means, standard deviations, internal consistencies (Cronbach's $\alpha$ ), and correlation (Pearson $r$ )

\begin{tabular}{l|c|c|c|c|c|c}
\hline Variables & Mean & SD & $\alpha$ & 1 & 2 & 3 \\
\hline 1- Gender & - & - & - & - & - & - \\
\hline 2- Age & 23.58 & 3.69 & - & -.023 & - & - \\
\hline 3- Masculine attributes & 4.24 & .82 & .75 & $-.13^{*}$ & -.04 & - \\
\hline 4- Feminine attributes & 3.37 & .80 & .80 & $.13^{*}$ & $.19^{* *}$ & .04 \\
\hline
\end{tabular}

${ }^{*} p \leq .05{ }^{* *} p \leq .01$

Table 2: Means, standard deviations of personal attributes

\begin{tabular}{l|c|c|l|c|c}
\hline Masculine items & Mean & SD & Feminine items & Mean & SD \\
\hline Athletic & 2.99 & 1.50 & Affectionate & 3.29 & 1.27 \\
\hline Strong personality & 5.73 & 1.00 & $\begin{array}{l}\text { Sensitive to the } \\
\text { needs of others }\end{array}$ & 4.80 & 1.43 \\
\hline Willing to take risks & 4.55 & 1.44 & Understanding & 4.91 & 1.30 \\
\hline Dominant & 5.10 & 1.45 & Compassionate & 3.92 & 1.44 \\
\hline Aggressive & 3.53 & 1.65 & Warm-hearted & 4.05 & 1.35 \\
\hline Act as a leader & 6.23 & 1.12 & Tender & 3.14 & 1.36 \\
\hline Individualistic & 2.96 & 1.61 & Loves children & 2.72 & 1.44 \\
\hline Hard-hearted & 4.55 & 1.42 & Cries easily & 1.71 & 1.00 \\
\hline Egoistic & 2.53 & 1.47 & Submissive & 1.84 & 0.98 \\
\hline
\end{tabular}


In particular, as Table 2 displays, the more valued personal attributes in order to perform accurately a top management position in a crisis organization were Act as a leader (masculine item), Strong personality (masculine item), Understanding (feminine item), and Sensitive to the needs of others (feminine item). On the contrary, Cries easily, Submissive, and Loves children, all of them feminine items, were the personal attributes less appreciated for a power and responsibility job in a crisis context.

The results of the ANOVA displayed in Table 3 show that male students preferred to a greater extent masculine traits in comparison to female students, whereas female students preferred to a greater extent feminine traits in comparison to male students. That is to say, traits associated traditionally to men were seen more appropriate among highly-qualified people to organizational management even in troubling times.

Table 3: Summary of ANOVA. Differences in Personal attributes depending on sample gender

\begin{tabular}{l|c|c|c|}
\hline Main variables & $\begin{array}{c}\text { Mean score of males } \\
\mathrm{N}=96\end{array}$ & $\begin{array}{c}\text { Mean score of females } \\
\mathrm{N}=144\end{array}$ & $\mathrm{p}$ \\
\hline Masculine attributes & 4.37 & 4.15 & .038 \\
\hline Feminine attributes & 3.24 & 3.46 & .044 \\
\hline
\end{tabular}

Finally, as we can see in Table 4, we found gender differences in the masculine items, Act as a leader and Aggressive. Male university students considered these personal attributes more appropriate for top management in a crisis situation than female students. Also we obtained gender differences in the feminine item of Compassionate: In this case, female university students perceived this personal attribute more appropriate for top management in a crisis situation than their peers.

Table 4: Summary of ANOVA. Differences in the different personal attribute items depending on sample gender

\begin{tabular}{l|c|c|c|l|c|c|c|}
\hline \multicolumn{1}{|c|}{ Masculine items } & $\begin{array}{c}\text { Mean } \\
\text { males } \\
\text { score } \\
\mathrm{N}=96\end{array}$ & $\begin{array}{c}\text { Mean } \\
\text { females } \\
\text { score } \\
\mathrm{N}=144\end{array}$ & $\mathrm{p}$ & Feminine items & $\begin{array}{c}\text { Mean } \\
\text { males } \\
\text { score } \\
\mathrm{N}=96\end{array}$ & $\begin{array}{c}\text { Mean } \\
\text { females } \\
\text { score } \\
\mathrm{N}=144\end{array}$ & $\mathrm{p}$ \\
\hline Athletic & 2.9 & 3.01 & .78 & Affectionate & 3.26 & 3.31 & .76 \\
\hline Strong personality & 5.80 & 5.69 & .39 & $\begin{array}{l}\text { Sensitive to the } \\
\text { needs of others }\end{array}$ & 4.64 & 4.92 & .13 \\
\hline Willing to take risks & 4.39 & 4.66 & .15 & Understanding & 4.80 & 4.98 & .30 \\
\hline Dominant & 5.29 & 4.97 & .09 & Compassionate & 3.46 & 4.22 & $<.001$ \\
\hline Aggressive & 4.06 & 3.17 & $<.001$ & Warm-hearted & 4.00 & 4.08 & .64 \\
\hline Act as a leader & 6.47 & 6.06 & .006 & Tender & 2.97 & 3.26 & .10 \\
\hline Individualistic & 2.98 & 2.95 & .89 & Loves children & 2.63 & 2.78 & .42 \\
\hline Hard-hearted & 4.73 & 4.43 & .11 & Cries easily & 1.65 & 1.75 & .43 \\
\hline Egoistic & 2.71 & 2.42 & .13 & Submissive & 1.83 & 1.85 & .91 \\
\hline
\end{tabular}

\section{CONCLUSIONS}

The aim of this study was to analyze which gender traits are considered more suitable in a leader in an organization which is facing a crisis and also to explore the gender differences in this topic. Regarding the first objective, the findings display that, in general terms, masculine attributes are clearly considered more accurate for a management positions in a company which is facing a crisis than feminine attributes. Specifically, the more appreciated personal attributes are Act as a leader (masculine item), Strong personality (masculine item), Understanding (feminine item), and Sensitive to the needs of others (feminine item). On the contrary, Cries easily, Submissive, and Loves children, all of them feminine items, are the personal attributes less appreciated for a power and responsibility job in a crisis context. Thus, despite there are feminine traits that the sample perceives as necessary as 
masculine traits, there are some feminine attributes which are considered hardly required for this kind of job. Consequently, agentic attributes are assessed as more appropriate for performing a top management position than the communal traits, even in a crisis context.

Moreover, we see ingroup favouritism, because we have found gender differences in some gender attributes. In particular, there are differences in the masculine items of Act as a leader and Aggressive. Male university students consider these personal attributes more appropriate for top management in a crisis situation than female students. Also we have obtained gender differences in the feminine item of Compassionate: In this case, female university students perceive this personal attribute more appropriate for top management in a crisis situation than their peers. It seems that the perception of suitability of some gender traits is influenced by the own gender role.

Our findings do not confirm "think crisis-think female" $[1,2,3]$. It could be due to the fact that perhaps the participants do not understand completely the hypothetical scenario. An alternative explanation is the fact that the "think manager-think male" is well established in our society. And even in nontraditional situations, such a crisis, where the communal traits seem more suitable, automatically, everything to do with the masculine domain emerges as the accurate option.

Our results confirm previous studies that concluded that the characteristics associated with success in performance management are closer to traits associated with men than to women [27, 28, 29]. This association of management with male characteristics obviously harms women in their selection or promotion for managerial positions, since precisely feminine traits predominate among women more than among men. In addition, women are also prejudiced on organizational decision-making processes on their promotion, training, and career plans. However, we also see in our results that certain traits which are associated with female gender, such as to be sensitive to the needs of others or understanding are also highly appreciated. This perhaps could be pointing to be a good leader must also incorporate communal characteristics related to ability to communicate, listen, teach, encourage. These qualities are closer to coaching and transformational leadership, the notion of transformational leader [16]. In addition, this phenomenon of "think manager-think male" far from disappearing is perpetuated and unfortunately perpetuates among men and women. Thus, as is clear from our results for the second objective of the study, male and female students agree in their perception that masculine attributes are more desirable to perform a managerial role than feminine characteristics.

These results show that overall the participants prefer the attributes traditionally more associated to men rather than to women. From the standpoint of this sample, issues such as management, power, or responsibility are still more characteristic of men than women. This result could be expected among male students, but it is shocking among the female students, who are often self-described in feminine terms, far more than the male students. Therefore, paradoxically, it seems that women, who precisely are studying a university degree, eliminate themselves in advance to management positions, because what is appropriate or desirable in these positions is not typical of their gender.

This paradox is a reflection of social practices and beliefs about the skills and abilities of men and women, who from an early age influence in shaping their self-concept. This self-concept takes hold in youth and is consolidated in the workplace. Therefore, if the purpose is to weaken the influence of beliefs, we must go to the source of purchase. So, the primary source of change is the education given in the spaces of socialization (i.e., family and school). One key factor lies in directing efforts towards promoting a model of coeducation [30]. Coeducation involves educating common and equal, discovering, reflecting, and acting on stereotypes in general and especially in those associated with the masculine/feminine. It is to transform the educational spaces of socialization on "coeducational social spaces". We propose to promote coordinated actions among the major agents of socialization (i.e., family, school, university, and organizations) to coordinate synchronically and diachronically the active task of coeducation.

\section{ACKNOWLEDGEMENTS}

This research is supported by a grant from the Spanish Ministry of Health, Social Services and Equality (2011-0004-INV-00014). 


\section{REFERENCES}

[1] Ryan, M.K., \& Haslam, S.A. (2005). The glass cliff: Evidence that women are over-represented in precarious leadership positions. British Journal of Management, 16, pp. 81-90.

[2] Haslam, S. A., \& Ryan, M. K. (2008). The road to the glass cliff: Differences in the perceived suitability of men and women for leadership positions in succeeding and failing organizations. Leadership Quarterly, 19, pp. 530-546.

[3] Ryan, M. K. \& Haslam, S. A. (2007). The glass cliff: Exploring the dynamics surrounding women's appointment to precarious leadership positions. Academy of Management Review, 32, pp. 549-572.

[4] Chernesky, R. H. (2003). Examining the glass ceiling: Gender influences on promotions decisions. Administration in Social Work, 27, pp. 13-18.

[5] Powell, G. N. (1999). Reflections on the ceiling glass. Recent trend and future prospects. In G. N. Powell (ed.): Handbook of gender and work. Sage Publications. Thousand Oaks, CA.

[6] Reid, M., Miller, W. \& Kerr, B. (2004). Sex-Based Glass Ceilings in U.S. State-Level Bureaucracies, 1987-1997. Administration \& Society, 36(4), pp. 377-405.

[7] van Vianen, A. E. M. \& Fischer, A. H. (2002). Illuminating the glass ceiling: The role of organizational culture preferences. Journal of Occupational and Organizational Psychology 75, pp. 315-337.

[8] ILO (2004). Romper el techo de cristal. Las mujeres en puestos de dirección. Actualización 2004. Geneva: International Labour Organization. Retrieved from: http://www.ilo.org/dyn/gender/docs/RES/292/F61986410/Romper\%20el\%20techo\%20de\%20cri $\underline{\text { stal.pdf }}$

[9] Barreto, M., Ryan, M. \& Schmitt, M. T. (2009). Introduction: Is the glass ceiling still relevant on the $21^{\text {st }}$ century? In The glass ceiling in the 21 st century: Understanding barriers to gender inequality American Psychological Association. Washington, DC.

[10] Morrison, A. M. White, R. P. \& van Velsor, E. (1987). Breaking the glass ceiling. AddisonWesley. Readin.

[11] Sarrió, M., Barberá, E., Ramos, A. \& Candela, C. (2002). El techo de cristal en la promoción profesional de las mujeres. Revista de Psicología Social 17(2), pp. 167-182.

[12] Heilman, M. E. (2001). Description and prescription: How gender stereotypes prevent women's ascent up the organizational ladder. Journal of Social Issues 57, pp. 657-674.

[13] Cuadrado, I., Navas, M., \& Molero, F. (2006). Mujeres y liderazgo. Claves psicosociales del Techo de Cristal. Sanz \& Torres. Madrid.

[14] Worchel, S., Cooper, J., Goethals, G. R. \& Olson, J. M. (2003). Psicología social. Thomsom Madrid.

[15] Eagly, A. H. \& Kite, M. E. (1987). Are stereotypes of nationalities applied to both women and men? Journal of Personality and Social Psychology 53, pp. 451-462.

[16] Eagly, A. H. \& Sczesny, S. (2009). Stereotypes about women, men, and leaders: Have times changed? In M. Barreto, M. Ryan, \& M. T. Schmitt (eds.): The glass ceiling in the 21st century: Understanding barriers to gender inequality American Psychological Association. Washington, DC.

[17] Bruckmüller, S., Ryan, M. K., Rink, F. \& Haslam, S.A. (2014). Beyond the Glass Ceiling: The Glass Cliff and Its Lessons for Organizational Policy. Social Issues and Policy Revie, 8, pp. 202232.

[18] Bruckmüller, S., \& Branscombe, N. R. (2010). The glass cliff: When and why women are selected as leaders in crisis contexts. British Journal of Social Psychology, 49, pp. 433-451.

[19] Rink, F., Ryan, M. K., \& Stoker, J. I. (2013). Clarifying the precariousness of the glass cliff: How social resources and gender stereotypes affect the evaluation of leaders in times of crisis. European Journal of Social Psychology, 43, pp. 381-392. 
[20] Ryan, M.K., Haslam, S.A., Hersby, M. D., Bongiorno, R. (2011). Think crisis-think female: Glass cliffs and contextual variation in the think manager-think male stereotype. Journal of Applied Psychology, 96, pp. 470 - 484.

[21] Turner, J. C., \& Haslam, S. A. (2001). Social identity, organizations and leadership. In: M. E. Turner (Ed.), Groups at work: Advances in theory and research (pp. 25-65). Hillsdale, NJ: Erlbaum.

[22] Eagly, A. H., \& Karau, S. J. (2002). Role congruity theory of prejudice toward female leaders. Psychological Review, 109, pp. 573-598.

[23] Gartzia, L., Ryan, M.K., Balluerka, N., \& Aritzeta, A. (2012). Think crisis-think female: Further evidence. European Journal of Work and Organizational Psychology, 21, pp. 603-628.

[24] Bem, S. L. (1974). The measurement of psychological androgyny. Journal of Consulting and Clinical Psycholog 42, pp. 155-62.

[25] Cuadrado I. (2004). Valores y rasgos estereotípicos de género de mujeres líderes. Psicothema 16, pp. 279-284.

[26] Nunnaly, J. C. (1978). Psychometric Theory. McGraw-Hill. New York.

[27] Schein, V. (1973). The relationship between sex role stereotypes and requisite managerial characteristics. Journal of Applied Psychology 57, pp. 95-100.

[28] Schein, V. (1975). The relationship between sex role stereotypes and requisite managerial characteristics among female managers. Journal of Applied Psychology 60, pp. 340-344.

[29] Schein, V. E. (2001). A global look at psychological barriers to women's progress in management. Journal of Social Issues 57, pp. 675-688.

[30] Lingard, B. (2003). Where to in gender policy in education after recuperative masculinity politics? International Journal of Inclusive Education 7(1), pp. 33-56. 